\title{
The role of laboratory diagnostics in emerging viral infections: the example of the Middle East respiratory syndrome epidemic
}

\author{
Jasper F. W. Chan ${ }^{1,2,3,4}$, Siddharth Sridhar ${ }^{2 \dagger}$, \\ Cyril C. Y. Yip ${ }^{2}$, Susanna K. P. Lau ${ }^{1,2,3,4}$, \\ and Patrick C. Y. Woo ${ }^{1,2,3,4 *}$ \\ ${ }^{1}$ State Key Laboratory of Emerging Infectious Diseases, ${ }^{2}$ Department of \\ Microbiology, Research Centre of Infection and Immunology, and \\ ${ }^{4} \mathrm{Carol} Y u$ Centre for Infection, The University of Hong Kong, Hong Kong \\ Special Administrative Region, P. R. China \\ (Received Jan 16, 2017 / Accepted Feb 9, 2017)
}

Rapidly emerging infectious disease outbreaks place a great strain on laboratories to develop and implement sensitive and specific diagnostic tests for patient management and infection control in a timely manner. Furthermore, laboratories also play a role in real-time zoonotic, environmental, and epidemiological investigations to identify the ultimate source of the epidemic, facilitating measures to eventually control the outbreak. Each assay modality has unique pros and cons; therefore, incorporation of a battery of tests using traditional culture-based, molecular and serological diagnostics into diagnostic algorithms is often required. As such, laboratories face challenges in assay development, test evaluation, and subsequent quality assurance. In this review, we describe the different testing modalities available for the ongoing Middle East respiratory syndrome (MERS) epidemic including cell culture, nucleic acid amplification, antigen detection, and antibody detection assays. Applications of such tests in both acute clinical and epidemiological investigation settings are highlighted. Using the MERS epidemic as an example, we illustrate the various challenges faced by laboratories in test development and implementation in the setting of a rapidly emerging infectious disease. Future directions in the diagnosis of MERS and other emerging infectious disease investigations are also highlighted.

Keywords: coronavirus, middle east, MERS, diagnosis, epidemic

\section{Introduction}

The ongoing threat of emerging viral infections to global pub-

${ }^{\dagger}$ These authors contributed equally to this work.

*For correspondence. E-mail: pcywoo@hku.hk

Copyright (C) 2017, The Microbiological Society of Korea lic health is well evidenced by the recent epidemics caused by Middle East respiratory syndrome coronavirus (MERS-CoV), avian influenza A viruses, Ebola virus, and Zika virus (To et al., 2013, 2014, 2015; Chan et al., 2015b, 2015c, 2016). Prompt and accurate diagnosis is the first step in the successful control of any of these epidemics, and is particularly important for emerging viral infections because they may spread rapidly and may be associated with severe complications (Sridhar et al., 2015). Definitive diagnosis of these emerging viral infections usually requires laboratory confirmation because their clinical features and epidemiological risk factors may be similar to those of other related infections. The characteristics of an ideal laboratory assay for diagnosing these infections include high sensitivity, high specificity, short turn-around time, low cost, low expertise, and facility requirement, suitability for use in different specimen types, availability for pointof-care testing (POCT), and capability to quantify viral load. Unfortunately, despite the recent advances in the field, no single laboratory diagnostic test has all of these characteristics. It is therefore important to understand the clinical applications of the various types of laboratory diagnostic assays and their roles in the control of emerging viral epidemics. In this review, we use the MERS epidemic as an example to illustrate the advantages, disadvantages, practical uses, and impact on epidemic control of the major types of laboratory diagnostic assays available for emerging viral infections.

\section{Overview of MERS-CoV and MERS}

Middle East respiratory syndrome coronavirus (MERS-CoV) is a novel lineage $\mathrm{C}$ betacoronavirus first isolated from a Saudi Arabian man with severe acute community-acquired pneumonia and acute kidney injury in 2012 (Zaki et al., 2012). As of 5 December 2016, 1864 cases of human MERS cases, including 659 fatalities, have been reported by the World Health Organization (http://who.int/emergencies/mers-cov/ en/). The epidemic has continued to expand since 2012, with most human cases of MERS being reported in the Middle East as a result of animal-to-human transmissions from infected animal reservoirs (dromedary camels and possibly bats in the region) and person-to-person transmissions in healthcare-associated outbreaks (Reusken et al., 2013a; Haagmans et al., 2014; Wang et al., 2014; Chan et al., 2015b). Moreover, sporadic cases and clusters of human MERS infection have also occurred in other areas with imported cases of MERS, such as the Republic of Korea (Cho et al., 2016). The clinical 
presentation of MERS may range from asymptomatic infection detected during contact tracing in outbreak investigations to rapidly fatal disease (Chan et al., 2015b). The disease is especially severe in elderly men with co-morbidities (Assiri et al., 2013a). Severe MERS is characterized by rapidly progressive acute pneumonia with fever and respiratory failure not responsive to broad-spectrum antibacterial treatment, and may be associated with extrapulmonary manifestations, including acute kidney injury, hepatic dysfunction, gastrointestinal symptoms, and seizures (Chan et al., 2012, 2013c; Zaki et al., 2012; Assiri et al., 2013a; Arabi et al., 2015). A number of repurposed drugs, antiviral peptides, and monoclonal antibodies have demonstrated anti-MERS-CoV activity in vitro and/or in animal models, but none of them have been proven to be effective in randomized controlled trials yet (Chan et al., 2013b, 2015d; Gao et al., 2013; Lu et al., 2014a; Jiang et al., 2014; Tang et al., 2014; Ying et al., 2014). Various vaccines have been developed and some are undergoing clinical trials and/or testing in camels (Uyeki et al., 2016).

\section{Specimen collection: what, when, and how?}

Like all other infectious diseases, appropriate specimen collection is the most important step in the laboratory diagnosis of MERS and requires knowledge of viral kinetics in various specimen types with relation to time since symptom onset. Like SARS-CoV, MERS-CoV viral loads in respiratory specimens peak in the second week after symptom onset (Chan et al., 2004; Oh et al., 2016). Therefore, a patient testing 'negative' for MERS soon after symptom onset should undergo repeated testing if epidemiological history is suggestive of MERS.

Lower respiratory tract specimens (including tracheal aspirates, bronchoalveolar lavage fluid, well collected sputum specimens) contain the highest viral RNA loads and should be collected whenever possible (Corman et al., 2016; Oh et al., 2016). However, invasive procedures to obtain lower respiratory specimens may not always be feasible, especially in patients with mild illness. Upper respiratory tract specimens (nasopharyngeal swabs, oropharyngeal swabs, and/or nasopharyngeal aspirates) should be taken for such cases with pooling of swabs in a single container to maximize RNA load as viral loads in the upper respiratory tract are consistently lower than in the lower respiratory tract (Memish et al., 2014b; Corman et al., 2016). Risk assessment regarding requisite transmission-based precautions, patient placement, and personal protective equipment during specimen collection should be conducted due to the possibility of aerosol generation. Specimens should be sent to the laboratory in viral transport medium containing a balanced salt solution, bovine serum albumin, $\mathrm{pH}$ buffer, phenol red, and antimicrobials as soon as possible. If specimen processing is likely to be delayed, storage in an ultra-low freezer $\left(-80^{\circ} \mathrm{C}\right)$ is recommended.

Extrapulmonary specimens that have been reported to contain detectable MERS-CoV RNA include blood, stool, and urine (Drosten et al., 2013; Poissy et al., 2014; Corman et al., 2016). These specimens may provide further opportunities for MERS diagnosis when lower respiratory tract specimens are unavailable. However, viral loads in these specimen types are generally lower than in the lower respiratory tract, although there are reported exceptions (Abroug et al., 2014). Detection of MERS-CoV in stool specimens may have infection control implications, while detection of MERS-CoV RNA in whole blood or serum in particular may be a prognostic marker of poor outcome (Guery et al., 2013; Kim et al., 2016c).

For serology testing, acute and convalescent serum specimens should ideally be collected 14 to 21 days apart to enable documentation of seroconversion or 4-fold rise in neu-

Table 1. Characteristics and applications of different diagnostic methods for MERS

\begin{tabular}{|c|c|c|c|c|}
\hline Diagnostic test & $\begin{array}{l}\text { Examples of commonly } \\
\text { used assays / cell lines }\end{array}$ & Advantages & Disadvantages & Other applications \\
\hline Viral culture & $\begin{array}{l}\text { Vero, LLC-MK2, Caco-2, } \\
\text { and Huh-7 cell lines }\end{array}$ & $\begin{array}{l}\text { - Especially useful in the initial phase } \\
\text { of emerging epidemics before other } \\
\text { diagnostic assays are available } \\
\text { - Considered as the gold standard of } \\
\text { virological diagnosis }\end{array}$ & $\begin{array}{l}\text { - Requires BSL-3 facility } \\
\text { - Requires at least 3-5 days }\end{array}$ & $\begin{array}{l}\text { - Pathogenesis studies } \\
\text { - Antiviral and vaccine } \\
\text { evaluation studies }\end{array}$ \\
\hline \multicolumn{5}{|l|}{ NAAT } \\
\hline Monoplex RT-PCR & upE and ORF1a assays & - Fast (hours to 1-2 days) & \multirow{3}{*}{$\begin{array}{l}\text { - Requires expertise and } \\
\text { specialized equipment } \\
\text { - Risk of amplicon carryover }\end{array}$} & \multirow{3}{*}{$\begin{array}{l}\text { - Contact tracing and animal } \\
\text { source finding } \\
\text { - Viral shedding patterns } \\
\text { - Prognostic markers } \\
\text { - Antiviral and vaccine } \\
\text { evaluation studies }\end{array}$} \\
\hline Multiplex RT-PCR & $\begin{array}{l}\text { Combined upE and ORF1a } \\
\text { assay }\end{array}$ & - Does not require BSL-3 facility & & \\
\hline $\begin{array}{l}\text { Non-PCR-based } \\
\text { assays }\end{array}$ & RT-LAMP and RT-RPA & & & \\
\hline $\begin{array}{l}\text { Antigen detection } \\
\text { assays }\end{array}$ & $\begin{array}{l}\text { Nucleocapsid protein } \\
\text { detection }\end{array}$ & $\begin{array}{l}\text { - Fast (minutes to hours) } \\
\text { - May allow point-of-care testing }\end{array}$ & $\begin{array}{l}\text { - Not yet thoroughly validated } \\
\text { for human clinical specimens } \\
\text { - Sensitivity is usually lower } \\
\text { than NAAT }\end{array}$ & $\begin{array}{l}\text { - Histological examination of } \\
\text { post-mortem human } \\
\text { samples and animal models }\end{array}$ \\
\hline $\begin{array}{l}\text { Antibody detection } \\
\text { assays }\end{array}$ & IFA, ELISA, PRNT & $\begin{array}{l}\text { - Most do not require BSL-3 facility } \\
\text { - Enables retrospective diagnosis }\end{array}$ & $\begin{array}{l}\text { - Some assays may show cross- } \\
\text { reactivity with other CoVs } \\
\text { - Requires cumbersome } \\
\text { confirmatory assays }\end{array}$ & $\begin{array}{l}\text { - Contact tracing in outbreak } \\
\text { investigations } \\
\text { - Seroepidemiological studies } \\
\text { in human and animals }\end{array}$ \\
\hline
\end{tabular}

Abbreviations: BSL-3, biosafety level 3; CoVs, coronaviruses; ELISA, enzyme-linked immunosorbent assay; IFA, immunofluorescence assay; NAAT, nucleic acid amplification tests; PRNT, plaque reduction neutralization test; RT-LAMP, reverse transcription-loop-mediated isothermal amplification; RT-PCR, reverse transcription-polymerase chain reaction; RT-RPA, reverse transcription isothermal recombinase polymerase amplification. 
tralizing antibody titer. When no serum specimen from the acute phase is available, a convalescent phase serum specimen may also be used to establish retrospective diagnosis with a panel of antibody tests (see Serology section below).

The choice of investigation will depend on the specimen type, timing post-symptom onset and local test availability. The advantages and shortcomings of different tests are detailed below and summarized in Table 1 .

\section{Viral culture: an important tool for virus disco- very, pathogenesis studies, and evaluation of countermeasures}

Isolation of infectious MERS-CoV in cell culture inoculated with the patient's bodily fluids and/or tissues establishes the diagnosis of MERS (Zaki et al., 2012). Although the routine use of viral culture for diagnosing MERS in standard clinical microbiology laboratories is limited by the method's relatively slower turn-around time than molecular diagnostics and requirement of a biosafety level 3 facility, this time-tested diagnostic tool has played important roles in the discovery and studies on the pathogenesis and antivirals of MERS-CoV. Unlike the other human-pathogenic CoVs which are notoriously difficult to culture in cell lines, MERS-CoV replicates rapidly with induction of prominent cytopathic effects in a broad range of cell lines (Muller et al., 2012; Chan et al., 2013a). MERS-CoV produces focal cytopathic effects with rounded refractile cells in susceptible cell lines within 5 days after inoculation during primary isolation (Chan et al., 2013a). The spread of these changes throughout the cell monolayers leads to rounding and detachment of cells within 1 to 2 days. Syncytium formation caused by fusion activity of the MERS-CoV spike (S) protein may be seen in Calu-3, Caco-2, Huh-7, and LLC-MK2 cell lines (Zaki et al., 2012; Chan et al., 2013a; de Wilde et al., 2013). These rapid and prominent cytopathic effects allowed Zaki and colleagues to successfully isolate the first MERS-CoV strain from cell lines which were commonly used in clinical virology laboratories (Vero and LLCMK2) shortly after inoculation of the index patient's sputum sample into these cell lines (Zaki et al., 2012).

A recent comparison between Vero and Caco-2 cell lines for the isolation of MERS-CoV showed that the isolation rate of MERS-CoV was significantly higher in Caco-2 than in Vero cells (45.5\% vs $19.1 \%, P=0.013$ ) (Muth et al., 2015). The isolation rate of MERS-CoV in cell culture was higher in respiratory samples with higher viral RNA loads $(66.7 \%$ vs $5.9 \%$ in samples with $\geq 10^{7}$ copies $/ \mathrm{ml}$ and $<10^{7}$ copies $/ \mathrm{ml}$, respectively), lower respiratory tract samples $(0.0 \%$ in nasopharyngeal aspirate, $33.3 \%$ in sputa, and $48.6 \%$ in endotracheal aspirates), and samples which were collected earlier after diagnosis $(58.6 \%$ vs $22.2 \%$ in samples collected within and after 5 days of diagnosis, respectively). These factors should be considered in laboratories which are attempting to isolate MERS-CoV from clinical specimens.

The broad tissue tropism of MERS-CoV in cell lines of different human organ tissue origins corroborated with the protean clinical manifestations of MERS in human. The high viral load of MERS-CoV in human lung, kidney, colonic, and hepatic cell lines correlate with the predominantly lower respiratory tract involvement and extrapulmonary manifestations of acute kidney injury, diarrhea, and hepatic dysfunction, respectively (Chan et al., 2015b). Most of these in vitro observations were subsequently validated in ex vivo organ tissue culture and/or animal models (Chan et al., 2013f; Zhou et al., 2014; Chu et al., 2016; Yeung et al., 2016). The replication of MERS-CoV in monocytes, dendritic cells, and $\mathrm{T}$ lymphocytes with aberrant induction of inflammatory cytokines/chemokines and activation of extrinsic and intrinsic apoptosis pathways partly explained the pathogenesis of virus dissemination, cytokine/chemokine storm, and lymphopenia in severe MERS (Lau et al., 2013a; Chu et al., 2014, 2016; Zhou et al., 2014, 2015; Scheuplein et al., 2015, Tynell et al., 2016). Moreover, MERS-CoV could be isolated from numerous non-human cell lines, including those of nonhuman primate, camel, and bat origins (Muller et al., 2012; Chan et al., 2013a; Eckerle et al., 2014). In contrast, cell lines of mouse and rat origins were not susceptible (Chan et al., 2013a). These in vitro biological characteristics of MERS$\mathrm{CoV}$ provided insights on the possible clinical manifestations, animal reservoirs, and animal species which were susceptible to MERS-CoV infection for animal model development at an early stage of the epidemic (de Wit et al., 2013a; Munster et al., 2013; Coleman et al., 2014; Falzarano et al., 2014; Yao et al., 2014; Zhao et al., 2014; Agrawal et al., 2015; Chan et al., 2015d; Haagmans et al., 2015). Viral culture of MERS-CoV also facilitated the identification and evaluation of anti-MERS-CoV drugs. Screening of potential candidate anti-MERS-CoV agents in chemical libraries consisting of a large number of clinically approved drugs and validation of their in vitro anti-MERS-CoV activity in cytopathic effect inhibition, viral load reduction, and plaque reduction assays using cell culture systems successfully identified repurposed drugs, such as type I interferons and lopinavir-ritonavir, for further testing in animal models (Chan et al., 2013b; Dyall et al., 2014; de Wilde et al., 2014). Similarly, the anti-MERS$\mathrm{CoV}$ effects of newly designed antiviral peptides and monoclonal antibodies were also validated in cell culture (Gao et al., 2013; Jiang et al., 2014; Lu et al., 2014a; Tang et al., 2014; Ying et al., 2014). The availability of viral culture for MERS$\mathrm{CoV}$ in reference research laboratories is crucial for further deepening our understanding on and finding countermeasures for MERS.

\section{Nucleic acid amplification tests: the platinum standard for MERS diagnosis}

Given the limitations of viral culture, more rapid and readily available laboratory assays were required for diagnosing MERS. Specific primers and a standardized laboratory protocol were quickly developed after the successful isolation of the first MERS-CoV strain and sequencing of its complete genome early in the epidemic in September 2012 (Palm et al., 2012). The positive sense, single-stranded RNA genome of MERS-CoV has a size of approximately $30 \mathrm{~kb}$ and is arranged in the order of 5 '-replicase [open reading frame (ORF) $1 \mathrm{a} / \mathrm{b}$ ]structural proteins [S-envelope (E)-membrane (M)-nucleocapsid (N)]-poly(A)-3' (Woo et al., 2012; Chan et al., 2013d; Lau et al., 2013b). A number of monoplex reverse transcrip- 
tion-polymerase chain reaction (RT-PCR) assays using primers that target conserved gene regions of the MERS-CoV genome were developed and evaluated for screening and/or confirmatory tests.

These gene targets include the leader sequence at the 5'untranslated region, and ORF1a, ORF1b, RNA-dependent RNA polymerase (RdRp), ORF4a, upE (upstream of envelope (E) gene), $\mathrm{M}$, and $\mathrm{N}$ gene regions (Corman et al., 2012a, 2012b; Lu et al., 2014b; Chan et al., 2015a; Douglas et al., 2015). The most commonly adopted diagnostic protocol utilizes the upE assay as a screening test, followed by either the ORF1a or ORF1b assays for confirmation. In general, these assays were highly sensitive and specific, with their technical limits of detection ranging from 1.6 to 263.0 RNA copies/reaction (Chan et al., 2015b; Kim et al., 2016b). The limits of detection appear to be the lowest in the assays targeting the abundantly expressed leader sequence at the 5'-untranslated region and the $\mathrm{N}$ gene, although clinical comparison among the various assays have not been reported. Most of these assays were evaluated using clinical specimens, including respiratory (nasopharyngeal aspirate, sputum, endotracheal aspirate, bronchoalveolar lavage fluid, and/or nose and mouth exudates) and/or extrapulmonary specimens (serum, urine, and/or stool). A number of regional and international external quality assessments showed that the majority (>80\%) of participating laboratories were capable of detecting MERS-CoV RNA by RT-PCR assays with high accuracy, but false-negative results might occur in a minority of samples with low viral loads (Pas et al., 2015; Seong et al., 2016; Zhang et al., 2016).

Recent advances in molecular diagnostics for MERS include the development of commercial monoplex and multiplex RT-PCR kits, and other novel non-PCR-based diagnostics. Most of the commercial assays utilize primers that target the upE and/or ORF1a gene regions (Corman et al., 2014; Kim et al., 2016b) (http://www.fast-trackdiagnostics. com/products/ftd-mers-cov/; http://eng.bioneer.com/diagnostic/HumanMDxkits/Accupower-MERS-CoV-Multiplexoverview.aspx; http://seegene.com/neo/en/products/respiratory/anyplex_mers_cov.php). Internal controls of these assays include primers against human glyceraldehyde 3-phosphate dehydrogenase gene, which is a housekeeping gene found in clinical specimens, spiked RNA, tobacco mosaic virus DNA, or phocine herpesvirus DNA spiked in the PCR mixtures. Analytical and clinical evaluation of these assays showed that they generally had high sensitivity and specificity, but false-negative or invalid results may occur in specimens containing high levels of PCR inhibitors, such as sputum specimens (Kim et al., 2016b). Sputum homogenization prior to nucleic acid extraction with proteinase $\mathrm{K}$ and DNase treatment may be more effective than either phosphate-buffered saline treatment or $\mathrm{N}$-acetyl-L-cysteine and sodium citrate treatment for improving the sensitivity of these assays (Sung et al., 2016). The performance of multiplex assays may be improved by the use of self-avoiding molecular recognition system-artificially expanded genetic information systems (SAMRS-AEGIS) primers to reduce non-specific reactions generated among the multiple primers in the same assay (Glushakova et al., 2015; Yaren et al., 2016). The main advantage of these commercial diagnostic kits is their ease for use in laboratories without technical expertise for designing and performing in-house-developed RT-PCR assays. The major disadvantage is their relatively high costs which may limit their use in resource-limited regions.

Other non-PCR-based assays for MERS include reverse transcription-loop-mediated isothermal amplification (RTLAMP) and reverse transcription isothermal recombinase polymerase amplification (RT-RPA) (Abd El Wahed et al., 2013; Shirato et al., 2014; Bhadra et al., 2015). These isothermal assays generally have short incubation times and are highly sensitive and specific. They are simple to perform and do not require thermocyclers, and are therefore especially suitable for POCT in resource-limited areas where the expertise and equipment for RT-PCR are not readily available.

In addition to establishing diagnosis, nucleic acid amplification tests have been applied to fulfill a number of other important purposes in the MERS epidemic. Firstly, it was used to investigate the animal reservoir of MERS-CoV and established the link between dromedary camels and human cases of MERS (Haagmans et al., 2014; Lau et al., 2016). The higher rate of detection of MERS-CoV RNA in the nasal and/or rectal swabs of juvenile camels than in those of adult camels further helped to identify juvenile camels as an important source of camel-to-human transmission of MERS (Alagaili et al., 2014; Wernery et al., 2015). Secondly, RT-PCR is commonly employed in contact tracing during healthcare-associated outbreaks of MERS (Assiri et al., 2013b; Memish et al., 2013; Drosten et al., 2014; Oboho et al., 2015). During these outbreak investigations, it was recognized that asymptomatic infection might occur in young and previously healthy persons and that they might serve as the source of further person-to-person transmission of MERS (Memish et al., 2013, 2014a; Omrani et al., 2013). Thirdly, serial testing of different clinical samples of MERS patients by RT-PCR identified the shedding patterns of the virus in respiratory and non-respiratory samples. Notably, viral RNA was detected in $14.6 \%$ of stool and $2.4 \%$ of urine samples, suggesting that these clinical samples may also be important in the spread of MERS. Fourthly, viral RNA load was found to be a predictive factor for severe disease. High MERS-CoV load in lower respiratory tract specimens was predictive of progression to pneumonia. Blood MERS-CoV RNA positivity at initial diagnosis was associated with worse clinical outcome in terms of a higher rate of requiring mechanical ventilation or extracorporeal membrane oxygenation, as well as death $(P<0.05)$. Fifthly, RT-PCR was commonly employed in in vitro and in vivo antiviral and vaccine evaluation studies (Zumla et al., 2016). Finally, RT-PCR and sequencing were important for surveying molecular epidemiological changes that may be associated with virus adaption for efficient person-toperson transmission.

\section{Antigen detection assays: potential for POCT}

Molecular diagnostic assays have excellent sensitivity for the diagnosis of MERS-CoV infection. However, these assays require dedicated facilities, expensive equipment and highly trained personnel, which places a great strain on laboratory 
infrastructure in endemic areas of MERS. Therefore, there has been considerable interest in developing MERS-CoV antigen detection assays, which are better than PCR diagnosis in terms of convenience.

Specific monoclonal antibodies targeting MERS-CoV proteins are used to demonstrate evidence of MERS-CoV in infected tissues (de Wit et al., 2013b). Such antibodies have also been used to detect the MERS-CoV N protein in respiratory specimens as this antigen is abundantly expressed during the acute phase of illness. Four assays for detection of the MERS-CoV N protein have been described to date (Chen et al., 2015, 2016; Song et al., 2015; Yamaoka et al., 2016). The peptides used to immunize mice for raising monoclonal antibodies were either in the form of recombinant protein synthetically produced by cloning the corresponding DNA fragment into E. coli and subsequently purifying the protein, or prepared using a wheat germ extract-based cell free expression system. Researchers either used a single long peptide or a pool of smaller synthetic peptides spanning the length of the MERS-CoV N protein (Chen et al., 2015, 2016; Song et al., 2015; Yamaoka et al., 2016).

Monoclonal antibodies that produced favorable signal-tonoise ratios in a recombinant MERS-CoV $\mathrm{N}$ protein immunoassay were selected for incorporation into either an enzyme-linked immunosorbent assay (ELISA) (Chen et al., 2015; Yamaoka et al., 2016) or a POCT format (Song et al., 2015; Chen et al., 2016).

The analytical sensitivity of antigen detection assays was measured using lower limit-of-detection (LOD) experiments. We have previously described an ELISA assay that had an LOD of $10 \mathrm{TCID}_{50} / 0.1 \mathrm{ml}$ using simulated NPA specimens seeded with serially diluted MERS-CoV cultures (Chen et al., 2015). A lateral flow immunoassay (LFIA), also described by us, had an LOD of at least $10^{3.7}$ TCID $_{50} / \mathrm{ml}$ MERS-CoV (Chen et al., 2016). An immunochromatographic test (ICT) developed by Song et al. had a LOD of $1.5 \mathrm{ng} / \mathrm{ml}$ recombinant MERS-CoV N protein while the ELISA assay developed by Yamaoka et al could detect $0.625 \mathrm{ng} / \mathrm{ml}$ of $\mathrm{N}$ protein (Song et al., 2015; Yamaoka et al., 2016). Due to careful selection of monoclonal antibodies, the published assays were quite specific for MERS-CoV and did not cross-react with other animal or human coronaviruses.

The main advantage of antigen detection assays is their ease of use and rapid results, especially when adapted to a POCT format. POCTs can be performed entirely within a biosafety cabinet, have built-in quality control and require minimal training of laboratory personnel. They offer a rapid and specific 'rule-in' option for clinicians while pending PCR tests, which may require send out to reference laboratories and long turnaround times in regions where laboratory infrastructure is not well developed.

However, there are several obstacles to the application of antigen detection for the diagnosis of MERS in humans. Firstly, such assays have not been validated in clinical specimens from suspected MERS cases in endemic areas. There is no head-to-head comparison with PCR, which is the most commonly employed 'platinum standard' diagnostic method in MERS patients. From experience with other respiratory viruses, the sensitivity is expected to be lower than PCR tests, which may provide false reassurance and lapses in infection control if false negative results are interpreted without a confirmatory PCR assay (Chan et al., 2002). Furthermore, antigen detection POCTs and ELISAs designed to date have only been evaluated using nasopharyngeal specimens; it is unknown whether such assays can be used on lower respiratory tract specimens, which are often observed to contain higher viral loads than NPA (Drosten et al., 2013; Guery et al., 2013) and would theoretically be even more suitable for antigen detection assays. Lastly, antigen detection assays do not feature in $\mathrm{WHO}$ or CDC algorithms for the diagnosis of MERS, limiting interest in developing commercial kits up to this stage (http://www.cdc.gov/coronavirus/mers/lab/lab-testing.html; http://apps.who.int/iris/bitstream/10665/176982/ 1/WHO_MERS_LAB_15.1_eng.pdf).

Antigen detection assays may have a potential role in the epidemiological surveillance of camels. The ICT developed by Song et al was validated using camel nasal swabs, demonstrating a high sensitivity (93.9\%) and specificity (99.6\%) compared to upE and ORF1A real time RT-PCR (Song et al., 2015). Our LFIA also showed a moderately high sensitivity of $81 \%$ with excellent specificity compared to real time RT-PCR on dromedary camel respiratory specimens (Chen et al., 2016). These studies indicate that such assays can be used for conveniently detecting infected camels in rural endemic areas.

\section{Antibody detection assays: retrospective diag- nosis and contact tracing}

Data regarding the kinetics of the antibody response in MERS patients is steadily accumulating. There appears to be considerable person-to-person variation in the robustness and timing of the antibody response, but as with other viral infections, an initial IgM response is followed by rising IgG titers, which is usually detectable 2 to 3 weeks after symptom onset (Drosten et al., 2013; Chan et al., 2015b; Park et al., 2015b). Longitudinal serology of one MERS-infected patient in China showed that anti-S ELISA antibodies rose before anti-N antibodies (Wang et al., 2016a). The differential kinetics of anti-N and anti-S antibodies in the setting of MERS serodiagnosis requires further study. Antibodies remain detectable long after clearance of infection; neutralizing antibodies were persistently detectable in $86 \%$ of patients up to 34 months after the Jordanian MERS outbreak of 2012 (Payne et al., 2016).

A wide variety of serological assays have been described for the detection of MERS-CoV-specific antibodies with variations in assay format, the antigen used and the antibody subtype detected. MERS specific IgM detection does not feature in diagnostic algorithms promulgated by the WHO or US CDC (http://www.cdc.gov/coronavirus/mers/lab/lab-testing.html; http://apps.who.int/iris/bitstream/10665/176982/ 1/WHO_MERS_LAB_15.1_eng.pdf). Although IgM titers theoretically rise before IgG, experience with sera from SARS and MERS patients suggests that the time lag between the two may be too short to be of much clinical value (Woo et al., 2004; Meyer et al., 2014a; Wang et al., 2016b). Furthermore, IgM assays are potentially prone to non-specific positivity and cross-reactivity with other coronaviruses requiring te- 
dious specimen preparation and quality control (Buchholz et al., 2013). The additional value of testing MERS-CoV IgM in patients presenting with acute illness requires further elucidation. In view of these factors, most of the serological assays described for MERS diagnosis either aim to detect total immunoglobulin or IgG.

A major variable in serological assays for MERS-CoV is the source of the antigen. For reference or research laboratories with BSL-3 and cell culture facilities, MERS-CoV-infected cells are the most convenient source of antigen. The cell lysate may be spotted on glass slides, microtiter plates or Western blot strips for downstream serological assays. Although convenient, such assays require a reliable means of inactivating live virus within the culture extracts. Furthermore, such assays have also been shown to cross react with other coronaviruses, as infected cells express a wide range of viral antigens, some of which are likely to be conserved across different coronavirus subgroups and even genera (Aburizaiza et al., 2014). For SARS, it has been shown that Western blotting with whole virus lysates may enable us to differentiate genuine seropatterns from false-positives; however, this is a tedious procedure requiring technical expertise and well characterized control sera (Guan et al., 2004).

In view of these shortcomings, recombinant antigens have been used for ELISA, immunofluorescence (IFA), Western blot, protein microarray and even pseudoparticle neutralization assays (Corman et al., 2012b; Perera et al., 2013; Reu- sken et al., 2013b; Chan et al., 2015b; Park et al., 2015a; Wang et al., 2016b). Using recombinant antigens has two major advantages: firstly, biosafety during assay production is not a major concern and secondly, this method enables the selection of immunogenic and MERS-CoV-specific antigens for maximizing assay specificity and sensitivity. Both viral $\mathrm{N}$ and $S$ proteins are abundantly expressed immunogenic antigens stimulating antibody production (Meyer et al., 2014a). In SARS patients, there is evidence that anti- $\mathrm{N}$ antibodies rise before anti-S antibodies (Woo et al., 2005). However, convalescent sera tend to react against both antigens with moderate to high sensitivity. The difference between the two antigens lies in their specificity. Although the $\mathrm{N}$ protein is easier to clone and purify (being smaller with fewer glycosylation sites), it is more conserved within coronavirus subgroups compared to the $S$ protein, which is the major target for neutralizing antibodies (Meyer et al., 2014a). Therefore, recombinant MERS-CoV $\mathrm{N}$ protein-based serological assays are expected to have higher rates of cross reactivity compared to anti-S detection assays. Indeed, $\mathrm{N}$ epitope cross reactivity may even extend across coronavirus genera: a SARS-CoV N protein-based ELISA showed a propensity to produce false positive results when tested against convalescent sera from patients recovering from $\mathrm{HCoV}-229 \mathrm{E}$ and even $\mathrm{HCoV}-\mathrm{OC} 43$ infections (Woo et al., 2005). However, there is evidence to suggest that even sections of the S2 subunit of the S protein can induce cross-reactive antibodies against different beta-

Table 2 Comparison of different antibody detection assays for MERS serodiagnosis

\begin{tabular}{|c|c|c|c|c|}
\hline Assay format & Variations & Antigen & Advantages & Disadvantages \\
\hline IFA & $\begin{array}{l}\text { - Conventional IFA } \\
\text { - Recombinant } \\
\text { antigen IFA }\end{array}$ & $\begin{array}{l}\text { - MERS-CoV-infected cell } \\
\text { lines } \\
\text { - Transfected cell lines } \\
\text { expressing MERS N \& S } \\
\text { protein }\end{array}$ & $\begin{array}{l}\text { - Can detect either anti-MERS-CoV IgG or } \\
\text { IgM subclasses } \\
\text { - Short processing time } \\
\text { - Antigens are presented with accurate } \\
\text { conformation and glycosylation } \\
\text { - Non-specific reactions may be identified } \\
\text { by experienced microscopist, considered to } \\
\text { be more specific than ELISA } \\
\text { - Commercial kit available }\end{array}$ & $\begin{array}{l}\text { - Requires experienced operators } \\
\text { - Potential for inter-observer variation } \\
\text { when reading titres } \\
\text { - Requires different conjugates for } \\
\text { humans and animals } \\
\text { - In-house design of conventional IFA } \\
\text { assay requires BSL-3 facility }\end{array}$ \\
\hline ELISA & $\cdot \mathrm{N} / \mathrm{A}$ & - S1 subunit of spike protein & $\begin{array}{l}\text { - Short processing time } \\
\text { - Straightforward assay procedure } \\
\text { - Large throughput } \\
\text { - Commercial kit available }\end{array}$ & $\begin{array}{l}\text { Potential for false-positives, } \\
\text { confirmatory assay recommended } \\
\text { - Requires different conjugates for } \\
\text { humans and camels }\end{array}$ \\
\hline Western Blot & $\cdot \mathrm{N} / \mathrm{A}$ & $\begin{array}{l}\text { - Lysate of transfected cells } \\
\text { expressing recombinant } \\
\text { MERS N \& S proteins }\end{array}$ & $\begin{array}{l}\text { - Potentially higher specificity compared to } \\
\text { ELISA }\end{array}$ & $\begin{array}{l}\text { - Very limited evaluation data } \\
\text { - Limited role in diagnostic algorithms } \\
\text { as more convenient assays available } \\
\text { for screening and more specific } \\
\text { assays available for confirmation }\end{array}$ \\
\hline $\begin{array}{l}\text { Protein } \\
\text { microarray }\end{array}$ & $\cdot$ N/A & - S1 subunit of spike protein & $\begin{array}{l}\text { - Allows for detection of IgG and IgM } \\
\text { subtypes } \\
\text { - One-stage, high throughput assay with } \\
\text { minimal sample requirement } \\
\text { - Antigen is correctly folded and } \\
\text { glycosylated } \\
\text { - Good specificity }\end{array}$ & $\begin{array}{l}\text { - Requires further evaluation of } \\
\text { diagnostic sensitivity by comparison } \\
\text { with neutralization assays }\end{array}$ \\
\hline \multirow[t]{2}{*}{ Neutralization } & $\begin{array}{l}\text { - PRNT } \\
\text { - Micro-neutralization }\end{array}$ & - Whole virus & - Gold-standard assay with high specificity & $\begin{array}{l}\text { - Cumbersome } \\
\text { - Requires several days for completion } \\
\text { - Requires BSL-3 facility }\end{array}$ \\
\hline & $\begin{array}{l}\text { - Pseudoparticle } \\
\text { neutralization assay }\end{array}$ & $\begin{array}{l}\text { - HIV/MERS-CoV } \\
\text { pseudoparticle expressing } \\
\text { MERS-CoV S protein }\end{array}$ & $\begin{array}{l}\text { - Comparable sensitivity and specificity to } \\
\text { conventional neutralization assays } \\
\text { - Does not require BSL-3 facility } \\
\text { - Objective signal detection using } \\
\text { luminometer }\end{array}$ & $\begin{array}{l}\text { - Needs further evaluation in clinical } \\
\text { specimens from MERS patients, but } \\
\text { performance data from South } \\
\text { Korean outbreak sera promising }\end{array}$ \\
\hline
\end{tabular}

Abbreviations: BSL, biosafety laboratory; ELISA, enzyme-linked immunosorbent assay; HIV, human immunodeficiency virus; IFA, immunofluorescence assay; Ig, immunoglobulin; MERS-CoV, Middle East respiratory syndrome coronavirus; N, nucleocapsid; N/A, not applicable; PRNT, plaque reduction neutralization test; S, spike. 
coronaviruses (Chan et al., 2013e). Further studies are required to elucidate optimally specific recombinant antigens for MERS serological tests.

Many of the classical serological assay formats have been applied to MERS with modifications in the interest of assay specificity and biosafety. The principles, advantages and disadvantages of each assay type are summarized in Table 2. Commercial IgG ELISA assays are now available and provide a fast and sensitive screening tool. Positive results by ELISA require confirmation by a more specific assay - either IFA or gold-standard neutralization assays.

Detailed evaluations for many of the published assays have not been possible because of a lack of well-characterized control sera. While the specificity of most assays can be assessed using sera of patients in non-endemic regions, diagnostic sensitivity and comparison-of-methods data are still difficult to come by. In a recent study, Park et al compared the plaque reduction neutralization test (PRNT), microneutralization and pseudoparticle neutralization tests using sera of 17 patients from the South Korean MERS outbreak (Park et al., 2015a). They found that the different neutralization test formats had excellent correlation with each other when testing convalescent clinical specimens.

In the first ten days after symptom onset, anti-MERS antibodies are usually undetectable irrespective of assay format (Park et al., 2015a, 2015b). Therefore, serology testing is not useful in acute MERS, although the WHO includes seroconversion (confirmed by neutralization) in paired sera taken at least 14 days apart as one of the diagnostic criteria for a confirmed case (http://apps.who.int/iris/bitstream/10665/176982/ 1/WHO_MERS_LAB_15.1_eng.pdf). The role of MERS serology, therefore, is threefold: firstly, to provisionally diagnose mild or asymptomatic MERS cases who present late with only convalescent sera available; secondly, for serosurveillance of at-risk individuals either as part of an outbreak investigation or in abattoirs where exposure to zoonotic sources may have occurred (Drosten et al., 2014; Muller et al., 2015; Kim et al., 2016a); thirdly, for seroepidemiological studies of zoonotic sources to identify affected camel herds. Indeed, demonstration of MERS-CoV neutralizing antibodies in camel sera is one of the lines of evidence for zoonotic transmission of MERS from camels to humans (Meyer et al., 2014b).

In view of the deficiencies of serological assays outlined in Table 2, most authorities recommend using at least two different assays for specific serodiagnosis of MERS. The WHO recommends using either an ELISA- or IFA-based screening assay followed by confirmatory testing of positive sera using a specific neutralization assay (http://apps.who.int/iris/bitstream/10665/176982/1/WHO_MERS_LAB_15.1_eng.pdf). The CDC also adopts a two-phase approach with the first test being an IgG ELISA followed by confirmatory testing using IFA (http://www.cdc.gov/coronavirus/mers/lab/labtesting.html). Microneutralization is performed on ELISApositive, IFA-indeterminate sera for final resolution.

\section{Conclusions and future perspectives}

The experience with MERS and other recent transnational epidemics proves that emerging infectious diseases will con- tinue to be a major challenge in the future. Rising human populations force animals and humans into ever closer proximity increasing the risk of zoonotic transmission of novel infectious diseases. Overcrowding facilitates human-to-human transmission of these infections, both in the community and in healthcare settings. High volumes of air travel enable rapid transport of infected humans to non-endemic regions leading to major outbreaks. All these features were clearly illustrated in the recent MERS epidemic. The key to combating these threats is information sharing, constant vigilance, and efficient infection control. The diagnostic laboratory plays an increasingly important role in the early detection of infected patients enabling prompt initiation of infection control measures and appropriate patient management. However, this role is a complex one requiring a battery of tests and diagnostic algorithms as highlighted in this review. The laboratory also faces several challenges in this role, related to assay validation, reagent shortages, a lack of standard materials, protocol standardization, and quality assurance. Creation of regional and global laboratory networks under the aegis of the $\mathrm{WHO}$ or other organizations will be crucial to overcome these difficulties. Pooling of positive control material for serological and molecular assays in biobanks would also be valuable. This is particularly important with the increasing introduction of massively multiplexed and point-of-care tests for the diagnosis of emerging infections, which is an emerging trend in the microbiology laboratory.

\section{Acknowledgements}

This work was partly supported by the Hong Kong Health and Medical Research Fund (15140762), the NSFC/RGC Joint Research Scheme (N_HKU728/14), the Theme-based Research Scheme (T11/707/15) of the Research Grants Council, Hong Kong Special Administrative Region, and Strategic Research Theme Fund from The University of Hong Kong.

\section{References}

Abd El Wahed, A., Patel, P., Heidenreich, D., Hufert, F.T., and Weidmann, M. 2013. Reverse transcription recombinase polymerase amplification assay for the detection of middle East respiratory syndrome coronavirus. PLoS Curr. 5, DOI: 10.1371/currents. outbreaks.62df1c7c75ffc96cd59034531e2e8364.

Abroug, F., Slim, A., Ouanes-Besbes, L., Hadj Kacem, M.A., Dachraoui, F., Ouanes, I., Lu, X., Tao, Y., Paden, C., Caidi, H., et al. 2014. Family cluster of Middle East respiratory syndrome coronavirus infections, Tunisia, 2013. Emerg. Infect. Dis. 20, 15271530.

Aburizaiza, A.S., Mattes, F.M., Azhar, E.I., Hassan, A.M., Memish, Z.A., Muth, D., Meyer, B., Lattwein, E., Muller, M.A., and Drosten, C. 2014. Investigation of anti-middle East respiratory syndrome antibodies in blood donors and slaughterhouse workers in Jeddah and Makkah, Saudi Arabia, fall 2012. J. Infect. Dis. 209, 243-246.

Agrawal, A.S., Garron, T., Tao, X., Peng, B.H., Wakamiya, M., Chan, T.S., Couch, R.B., and Tseng, C.T. 2015. Generation of a transgenic mouse model of Middle East respiratory syndrome coronavirus infection and disease. J. Virol. 89, 3659-3670.

Alagaili, A.N., Briese, T., Mishra, N., Kapoor, V., Sameroff, S.C., 
Burbelo, P.D., de Wit, E., Munster, V.J., Hensley, L.E., Zalmout, I.S., et al. 2014. Middle East respiratory syndrome coronavirus infection in dromedary camels in Saudi Arabia. MBio 5, e0088400814.

Arabi, Y.M., Harthi, A., Hussein, J., Bouchama, A., Johani, S., Hajeer, A.H., Saeed, B.T., Wahbi, A., Saedy, A., AlDabbagh, T., et al. 2015. Severe neurologic syndrome associated with Middle East respiratory syndrome corona virus (MERS-CoV). Infection 43, 495-501.

Assiri, A., Al-Tawfiq, J.A., Al-Rabeeah, A.A., Al-Rabiah, F.A., AlHajjar, S., Al-Barrak, A., Flemban, H., Al-Nassir, W.N., Balkhy, H.H., Al-Hakeem, R.F., et al. 2013a. Epidemiological, demographic, and clinical characteristics of 47 cases of Middle East respiratory syndrome coronavirus disease from Saudi Arabia: a descriptive study. Lancet Infect. Dis. 13, 752-761.

Assiri, A., McGeer, A., Perl, T.M., Price, C.S., Al Rabeeah, A.A., Cummings, D.A., Alabdullatif, Z.N., Assad, M., Almulhim, A., Makhdoom, H., et al. 2013b. Hospital outbreak of Middle East respiratory syndrome coronavirus. N. Engl. J. Med. 369, 407416.

Bhadra, S., Jiang, Y.S., Kumar, M.R., Johnson, R.F., Hensley, L.E., and Ellington, A.D. 2015. Real-time sequence-validated loop-mediated isothermal amplification assays for detection of Middle East respiratory syndrome coronavirus (MERS-CoV). PLoS One $\mathbf{1 0}$ e0123126.

Buchholz, U., Muller, M.A., Nitsche, A., Sanewski, A., Wevering, N., Bauer-Balci, T., Bonin, F., Drosten, C., Schweiger, B., Wolff, T., et al. 2013. Contact investigation of a case of human novel coronavirus infection treated in a German hospital, October-November 2012. Euro Surveill. 18, pii: 20406.

Chan, J.F., Chan, K.H., Choi, G.K., To, K.K., Tse, H., Cai, J.P., Yeung, M.L., Cheng, V.C., Chen, H., Che, X.Y., et al. 2013a. Differential cell line susceptibility to the emerging novel human betacoronavirus 2c EMC/2012: implications for disease pathogenesis and clinical manifestation. J. Infect. Dis. 207, 1743-1752.

Chan, J.F., Chan, K.H., Kao, R.Y., To, K.K., Zheng, B.J., Li, C.P., Li, P.T., Dai, J., Mok, F.K., Chen, H., et al. 2013b. Broad-spectrum antivirals for the emerging Middle East respiratory syndrome coronavirus. J. Infect. 67, 606-616.

Chan, J.F., Choi, G.K., Tsang, A.K., Tee, K.M., Lam, H.Y., Yip, C.C., To, K.K., Cheng, V.C., Yeung, M.L., Lau, S.K., et al. 2015 a. Development and evaluation of novel real-time reverse transcription-PCR assays with locked nucleic acid probes targeting leader sequences of human-pathogenic coronaviruses. J. Clin. Microbiol. 53, 2722-2726.

Chan, J.F., Choi, G.K., Yip, C.C., Cheng, V.C., and Yuen, K.Y. 2016. Zika fever and congenital Zika syndrome: An unexpected emerging arboviral disease. J. Infect. 72, 507-524.

Chan, J.F., Lau, S.K., To, K.K., Cheng, V.C., Woo, P.C., and Yuen, K.Y. 2015b. Middle East respiratory syndrome coronavirus: another zoonotic betacoronavirus causing SARS-like disease. Clin. Microbiol. Rev. 28, 465-522.

Chan, J.F., Lau, S.K., and Woo, P.C. 2013c. The emerging novel Middle East respiratory syndrome coronavirus: the "knowns" and "unknowns". J. Formos. Med. Assoc. 112, 372-381.

Chan, J.F., Li, K.S., To, K.K., Cheng, V.C., Chen, H., and Yuen, K.Y. 2012. Is the discovery of the novel human betacoronavirus $2 \mathrm{c}$ EMC/2012 (HCoV-EMC) the beginning of another SARS-like pandemic? J. Infect. 65, 477-489.

Chan, J.F., To, K.K., Chen, H., and Yuen, K.Y. 2015c. Cross-species transmission and emergence of novel viruses from birds. Curr. Opin. Virol. 10, 63-69.

Chan, J.F., To, K.K., Tse, H., Jin, D.Y., and Yuen, K.Y. 2013d. Interspecies transmission and emergence of novel viruses: lessons from bats and birds. Trends Microbiol. 21, 544-555.

Chan, J.F., Yao, Y., Yeung, M.L., Deng, W., Bao, L., Jia, L., Li, F., Xiao, C., Gao, H., Yu, P., et al. 2015d. Treatment with lopinavir/ ritonavir or interferon-betalb improves outcome of MERS-CoV infection in a nonhuman primate model of common marmoset. J. Infect. Dis. 212, 1904-1913.

Chan, K.H., Chan, J.F., Tse, H., Chen, H., Lau, C.C., Cai, J.P., Tsang, A.K., Xiao, X., To, K.K., Lau, S.K., et al. 2013e. Cross-reactive antibodies in convalescent SARS patients' sera against the emerging novel human coronavirus EMC (2012) by both immunofluorescent and neutralizing antibody tests. J. Infect. 67, 130140.

Chan, K.H., Maldeis, N., Pope, W., Yup, A., Ozinskas, A., Gill, J., Seto, W.H., Shortridge, K.F., and Peiris, J.S. 2002. Evaluation of the Directigen FluA+B test for rapid diagnosis of influenza virus type A and B infections. J. Clin. Microbiol. 40, 1675-1680.

Chan, K.H., Poon, L.L., Cheng, V.C., Guan, Y., Hung, I.F., Kong, J., Yam, L.Y., Seto, W.H., Yuen, K.Y., and Peiris, J.S. 2004. Detection of SARS coronavirus in patients with suspected SARS. Emerg. Infect. Dis. 10, 294-299.

Chan, R.W., Chan, M.C., Agnihothram, S., Chan, L.L., Kuok, D.I., Fong, J.H., Guan, Y., Poon, L.L., Baric, R.S., Nicholls, J.M., et al. 2013f. Tropism of and innate immune responses to the novel human betacoronavirus lineage $\mathrm{C}$ virus in human ex vivo respiratory organ cultures. J. Virol. 87, 6604-6614.

Chen, Y., Chan, K.H., Hong, C., Kang, Y., Ge, S., Chen, H., Wong, E.Y., Joseph, S., Patteril, N.G., Wernery, U., et al. 2016. A highly specific rapid antigen detection assay for on-site diagnosis of MERS. J. Infect. 73, 82-84.

Chen, Y., Chan, K.H., Kang, Y., Chen, H., Luk, H.K., Poon, R.W., Chan, J.F., Yuen K.Y., Xia, N., Lau, S.K., et al. 2015. A sensitive and specific antigen detection assay for Middle East respiratory syndrome coronavirus. Emerg. Microbes Infect. 4, e26.

Cho, S.Y., Kang, J.M., Ha, Y.E., Park, G.E., Lee, J.Y., Ko, J.H., Lee, J.Y., Kim, J.M., Kang, C.I., Jo, I.J., et al. 2016. MERS-CoV outbreak following a single patient exposure in an emergency room in South Korea: an epidemiological outbreak study. Lancet 388, 994-1001.

Chu, H., Zhou, J., Wong, B.H., Li, C., Chan, J.F., Cheng, Z.S., Yang, D., Wang, D., Lee, A.C., Li, C., et al. 2016. Middle East respiratory syndrome coronavirus efficiently infects human primary $\mathrm{T}$ lymphocytes and activates the extrinsic and intrinsic apoptosis pathways. J. Infect. Dis. 213, 904-914.

Chu, H., Zhou, J., Wong, B.H., Li, C., Cheng, Z.S., Lin, X., Poon, V.K., Sun, T., Lau, C.C., Chan, J.F., et al. 2014. Productive replication of Middle East respiratory syndrome coronavirus in monocyte-derived dendritic cells modulates innate immune response. Virology 454-455, 197-205.

Coleman, C.M., Matthews, K.L., Goicochea, L., and Frieman, M.B. 2014. Wild-type and innate immune-deficient mice are not susceptible to the Middle East respiratory syndrome coronavirus. J. Gen. Virol. 95, 408-412.

Corman, V.M., Albarrak, A.M., Omrani, A.S., Albarrak, M.M., Farah, M.E., Almasri, M., Muth, D., Sieberg, A., Meyer, B., Assiri, A.M., et al. 2016. Viral shedding and antibody response in 37 patients with Middle East respiratory syndrome coronavirus infection. Clin. Infect. Dis. 62, 477-483.

Corman, V.M., Eckerle, I., Bleicker, T., Zaki, A., Landt, O., EschbachBludau, M., van Boheemen, S., Gopal, R., Ballhause, M., Bestebroer, T.M., et al. 2012a. Detection of a novel human coronavirus by real-time reverse-transcription polymerase chain reaction. Euro Surveill. 17, pii: 20285.

Corman, V.M., Muller, M.A., Costabel, U., Timm, J., Binger, T., Meyer, B., Kreher, P., Lattwein, E., Eschbach-Bludau, M., Nitsche, A., et al. 2012b. Assays for laboratory confirmation of novel human coronavirus (hCoV-EMC) infections. Euro Surveill. 17, pii: 20334.

Corman, V.M., Olschlager, S., Wendtner, C.M., Drexler, J.F., Hess, M., and Drosten, C. 2014. Performance and clinical validation of the RealStar MERS-CoV kit for detection of Middle East res- 
piratory syndrome coronavirus RNA. J. Clin. Virol. 60, 168-171. de Wilde, A.H., Jochmans, D., Posthuma, C.C., Zevenhoven-Dobbe, J.C., van Nieuwkoop, S., Bestebroer, T.M., van den Hoogen, B.G., Neyts, J., and Snijder, E.J. 2014. Screening of an FDA-approved compound library identifies four small-molecule inhibitors of Middle East respiratory syndrome coronavirus replication in cell culture. Antimicrob. Agents Chemother. 58, 48754884.

de Wilde, A.H., Raj, V.S., Oudshoorn, D., Bestebroer, T.M., van Nieuwkoop, S., Limpens, R.W., Posthuma, C.C., van der Meer, Y., Barcena, M., Haagmans, B.L., et al. 2013. MERS-coronavirus replication induces severe in vitro cytopathology and is strongly inhibited by cyclosporin A or interferon-alpha treatment. J. Gen. Virol. 94, 1749-1760.

de Wit, E., Prescott, J., Baseler, L., Bushmaker, T., Thomas, T., Lackemeyer, M.G., Martellaro, C., Milne-Price, S., Haddock, E., Haagmans, B.L., et al. 2013a. The Middle East respiratory syndrome coronavirus (MERS-CoV) does not replicate in Syrian hamsters. PLoS One 8, e69127.

de Wit, E., Rasmussen, A.L., Falzarano, D., Bushmaker, T., Feldmann, F., Brining, D.L., Fischer, E.R., Martellaro, C., Okumura, A., Chang, J., et al. 2013b. Middle East respiratory syndrome coronavirus (MERS-CoV) causes transient lower respiratory tract infection in rhesus macaques. Proc. Natl. Acad. Sci. USA 110, 16598-16603.

Douglas, C.E., Kulesh, D.A., Jaissle, J.G., and Minogue, T.D. 2015. Real-time reverse transcriptase polymerase chain reaction assays for Middle East Respiratory Syndrome. Mol. Cell Probes 29, 511513.

Drosten, C., Meyer, B., Muller, M.A., Corman, V.M., Al-Masri, M., Hossain, R., Madani, H., Sieberg, A., Bosch, B.J., Lattwein, E., et al. 2014. Transmission of MERS-coronavirus in household contacts. N. Engl. J. Med. 371, 828-835.

Drosten, C., Seilmaier, M., Corman, V.M., Hartmann, W., Scheible, G., Sack, S., Guggemos, W., Kallies, R., Muth, D., Junglen, S., et al. 2013. Clinical features and virological analysis of a case of Middle East respiratory syndrome coronavirus infection. Lancet Infect. Dis. 13, 745-751.

Dyall, J., Coleman, C.M., Hart, B.J., Venkataraman, T., Holbrook, M.R., Kindrachuk, J., Johnson, R.F., Olinger, G.G., Jahrling, P.B., Laidlaw, M., et al. 2014. Repurposing of clinically developed drugs for treatment of Middle East respiratory syndrome coronavirus infection. Antimicrob. Agents Chemother. 58, 4885-4893.

Eckerle, I., Corman, V.M., Muller, M.A., Lenk, M., Ulrich, R.G., and Drosten, C. 2014. Replicative capacity of MERS coronavirus in livestock cell lines. Emerg. Infect. Dis. 20, 276-279.

Falzarano, D., de Wit, E., Feldmann, F., Rasmussen, A.L., Okumura, A., Peng, X., Thomas, M.J., van Doremalen, N., Haddock, E., Nagy, L., et al. 2014. Infection with MERS-CoV causes lethal pneumonia in the common marmoset. PLoS Pathog. 10, e1004250.

Gao, J., Lu, G., Qi, J., Li, Y., Wu, Y., Deng, Y., Geng, H., Li, H., Wang, Q., Xiao, H., et al. 2013. Structure of the fusion core and inhibition of fusion by a heptad repeat peptide derived from the $S$ protein of Middle East respiratory syndrome coronavirus. J. Virol. 87, 13134-13140.

Glushakova, L.G., Sharma, N., Hoshika, S., Bradley, A.C., Bradley, K.M., Yang, Z., and Benner, S.A. 2015. Detecting respiratory viral RNA using expanded genetic alphabets and self-avoiding DNA. Anal. Biochem. 489, 62-72.

Guan, M., Chen, H.Y., Tan, P.H., Shen, S., Goh, P.Y., Tan, Y.J., Pang, P.H., Lu, Y., Fong, P.Y., and Chin, D. 2004. Use of viral lysate antigen combined with recombinant protein in Western immunoblot assay as confirmatory test for serodiagnosis of severe acute respiratory syndrome. Clin. Diagn. Lab. Immunol. 11, 1148-1153.

Guery, B., Poissy, J., el Mansouf, L., Sejourne, C., Ettahar, N., Lemaire, X., Vuotto, F., Goffard, A., Behillil, S., Enouf, V., et al. 2013. Clinical features and viral diagnosis of two cases of infection with Middle East Respiratory Syndrome coronavirus: a report of nosocomial transmission. Lancet 381, 2265-2272.

Haagmans, B.L., Al Dhahiry, S.H., Reusken, C.B., Raj, V.S., Galiano, M., Myers, R., Godeke, G.J., Jonges, M., Farag, E., Diab, A., et al. 2014. Middle East respiratory syndrome coronavirus in dromedary camels: an outbreak investigation. Lancet Infect. Dis. 14, 140145.

Haagmans, B.L., van den Brand, J.M., Provacia, L.B., Raj, V.S., Stittelaar, K.J., Getu, S., de Waal, L., Bestebroer, T.M., van Amerongen, G., Verjans, G.M., et al. 2015. Asymptomatic Middle East respiratory syndrome coronavirus infection in rabbits. J. Virol. 89, 6131-6135.

Jiang, L., Wang, N., Zuo, T., Shi, X., Poon, K.M., Wu, Y., Gao, F., Li, D., Wang, R., Guo, J., et al. 2014. Potent neutralization of MERSCoV by human neutralizing monoclonal antibodies to the viral spike glycoprotein. Sci. Transl. Med. 6, 234 ra259.

Kim, C.J., Choi, W.S., Jung, Y., Kiem, S., Seol, H.Y., Woo, H.J., Choi, Y.H., Son, J.S., Kim, K.H., Kim, Y.S., et al. 2016a. Surveillance of the Middle East respiratory syndrome (MERS) coronavirus (CoV) infection in healthcare workers after contact with confirmed MERS patients: incidence and risk factors of MERS-CoV seropositivity. Clin. Microbiol. Infect. 22, 880-886.

Kim, M.N., Ko, Y.J., Seong, M.W., Kim, J.S., Shin, B.M., and Sung, H. 2016b. Analytical and clinical validation of six commercial Middle East respiratory syndrome coronavirus RNA Detection kits based on real-time reverse-transcription PCR. Ann. Lab. Med. 36, 450-456.

Kim, S.Y., Park, S.J., Cho, S.Y., Cha, R.H., Jee, H.G., Kim, G., Shin, H.S., Kim, Y., Jung, Y.M., Yang, J.S., et al. 2016c. Viral RNA in blood as indicator of severe outcome in Middle East respiratory syndrome coronavirus infection. Emerg. Infect. Dis. 22, 1813-1816.

Lau, S.K., Lau, C.C., Chan, K.H., Li, C.P., Chen, H., Jin, D.Y., Chan, J.F., Woo, P.C., and Yuen, K.Y. 2013a. Delayed induction of proinflammatory cytokines and suppression of innate antiviral response by the novel Middle East respiratory syndrome coronavirus: implications for pathogenesis and treatment. J. Gen. Virol. 94, 2679-2690.

Lau, S.K., Li, K.S., Tsang, A.K., Lam, C.S., Ahmed, S., Chen, H., Chan, K.H., Woo, P.C., and Yuen, K.Y. 2013b. Genetic characterization of Betacoronavirus lineage $\mathrm{C}$ viruses in bats reveals marked sequence divergence in the spike protein of pipistrellus bat coronavirus HKU5 in Japanese pipistrelle: implications for the origin of the novel Middle East respiratory syndrome coronavirus. J. Virol. 87, 8638-8650.

Lau, S.K., Wernery, R., Wong, E.Y., Joseph, S., Tsang, A.K., Patteril, N.A., Elizabeth, S.K., Chan, K.H., Muhammed, R., Kinne, J., et al. 2016. Polyphyletic origin of MERS coronaviruses and isolation of a novel clade A strain from dromedary camels in the United Arab Emirates. Emerg. Microbes Infect. 5, e128.

Lu, L., Liu, Q., Zhu, Y., Chan, K.H., Qin, L., Li, Y., Wang, Q., Chan, J.F., Du, L., Yu, F., et al. 2014a. Structure-based discovery of Middle East respiratory syndrome coronavirus fusion inhibitor. Nat. Commun. 5, 3067.

Lu, X., Whitaker, B., Sakthivel, S.K., Kamili, S., Rose, L.E., Lowe, L., Mohareb, E., Elassal, E.M., Al-sanouri, T., Haddadin, A., et al. 2014b. Real-time reverse transcription-PCR assay panel for Middle East respiratory syndrome coronavirus. J. Clin. Microbiol. 52, 67-75.

Memish, Z.A., Al-Tawfiq, J.A., Assiri, A., AlRabiah, F.A., Al Hajjar, S., Albarrak, A., Flemban, H., Alhakeem, R.F., Makhdoom, H.Q., Alsubaie, S., et al. 2014a. Middle East respiratory syndrome coronavirus disease in children. Pediatr. Infect. Dis. J. 33, 904-906.

Memish, Z.A., Al-Tawfiq, J.A., Makhdoom, H.Q., Assiri, A., Alhakeem, R.F., Albarrak, A., Alsubaie, S., Al-Rabeeah, A.A., Hajomar, W.H., Hussain, R., et al. 2014b. Respiratory tract samples, viral load, and genome fraction yield in patients with Middle East respiratory syndrome. J. Infect. Dis. 210, 1590-1594.

Memish, Z.A., Zumla, A.I., and Assiri, A. 2013. Middle East respi- 
ratory syndrome coronavirus infections in health care workers. N. Engl. J. Med. 369, 884-886.

Meyer, B., Drosten, C., and Muller, M.A. 2014a. Serological assays for emerging coronaviruses: challenges and pitfalls. Virus Res. 194, 175-183.

Meyer, B., Muller, M.A., Corman, V.M., Reusken, C.B., Ritz, D., Godeke, G.J., Lattwein, E., Kallies, S., Siemens, A., van Beek, J., et al. 2014b. Antibodies against MERS coronavirus in dromedary camels, United Arab Emirates, 2003 and 2013. Emerg. Infect. Dis. 20, 552-559.

Muller, M.A., Meyer, B., Corman, V.M., Al-Masri, M., Turkestani, A., Ritz, D., Sieberg, A., Aldabbagh, S., Bosch, B.J., Lattwein, E., et al. 2015. Presence of Middle East respiratory syndrome coronavirus antibodies in Saudi Arabia: a nationwide, cross-sectional, serological study. Lancet Infect. Dis. 15, 559-564.

Muller, M.A., Raj, V.S., Muth, D., Meyer, B., Kallies, S., Smits, S.L., Wollny, R., Bestebroer, T.M., Specht, S., Suliman, T., et al. 2012. Human coronavirus EMC does not require the SARS-coronavirus receptor and maintains broad replicative capability in mammalian cell lines. MBio 3, pii: e00515-12.

Munster, V.J., de Wit, E., and Feldmann, H. 2013. Pneumonia from human coronavirus in a macaque model. N. Engl. J. Med. 368, 1560-1562.

Muth, D., Corman, V.M., Meyer, B., Assiri, A., Al-Masri, M., Farah, M., Steinhagen, K., Lattwein, E., Al-Tawfiq, J.A., Albarrak, A., et al. 2015. Infectious Middle East respiratory syndrome coronavirus excretion and serotype variability based on live virus isolates from patients in Saudi Arabia. J. Clin. Microbiol. 53, 29512955.

Oboho, I.K., Tomczyk, S.M., Al-Asmari, A.M., Banjar, A.A., AlMugti, H., Aloraini, M.S., Alkhaldi, K.Z., Almohammadi, E.L., Alraddadi, B.M., Gerber, S.I., et al. 2015. 2014 MERS-CoV outbreak in Jeddah--a link to health care facilities. N. Engl. J. Med. 372, 846-854.

Oh, M.D., Park, W.B., Choe, P.G., Choi, S.J., Kim, J.I., Chae, J., Park, S.S., Kim, E.C., Oh, H.S., Kim, E.J., et al. 2016. Viral load kinetics of MERS coronavirus infection. N. Engl. J. Med. 375, 1303-1305.

Omrani, A.S., Matin, M.A., Haddad, Q., Al-Nakhli, D., Memish, Z.A., and Albarrak, A.M. 2013. A family cluster of Middle East Respiratory Syndrome Coronavirus infections related to a likely unrecognized asymptomatic or mild case. Int. J. Infect. Dis. 17, e668-672.

Palm, D., Pereyaslov D., Vaz, J., Broberg, E., Zeller, H., Gross, D., Brown, C.S., Struelens, M.J., Joint ECDC-WHO Regional Office for Europe Novel Coronavirus Laboratory Survey participants, ECDC National Microbiology Focal Points, et al. 2012. Laboratory capability for molecular detection and confirmation of novel coronavirus in Europe, November 2012. Euro Surveill. 17, pii: 20335.

Park, S.W., Perera, R.A., Choe, P.G., Lau, E.H., Choi, S.J., Chun, J.Y., Oh, H.S., Song, K.H., Bang, J.H., Kim, E.S., et al. 2015a. Comparison of serological assays in human Middle East respiratory syndrome (MERS)-coronavirus infection. Euro Surveill. 20, pii= 30042.

Park, W.B., Perera, R.A., Choe, P.G., Lau, E.H., Choi, S.J., Chun, J.Y., Oh, H.S., Song, K.H., Bang, J.H., Kim, E.S., et al. 2015b. Kinetics of serologic responses to MERS Coronavirus infection in humans, South Korea. Emerg. Infect. Dis. 21, 2186-2189.

Pas, S.D., Patel, P., Reusken, C., Domingo, C., Corman, V.M., Drosten, C., Dijkman, R., Thiel, V., Nowotny, N., Koopmans, M.P., et al. 2015. First international external quality assessment of molecular diagnostics for Mers-CoV. J. Clin. Virol. 69, 81-85.

Payne, D.C., Iblan, I., Rha, B., Alqasrawi, S., Haddadin, A., Al Nsour, M., Alsanouri, T., Ali, S.S., Harcourt, J., Miao, C., et al. 2016. Persistence of antibodies against Middle East respiratory syndrome coronavirus. Emerg. Infect. Dis. 22, 1824-1826.

Perera, R.A., Wang, P., Gomaa, M.R., El-Shesheny, R., Kandeil, A.,
Bagato, O., Siu, L.Y., Shehata, M.M., Kayed, A.S., Moatasim, Y., et al. 2013. Seroepidemiology for MERS coronavirus using microneutralisation and pseudoparticle virus neutralisation assays reveal a high prevalence of antibody in dromedary camels in Egypt, June 2013. Euro Surveill. 18, pii=20574.

Poissy, J., Goffard, A., Parmentier-Decrucq, E., Favory, R., Kauv, M., Kipnis, E., Mathieu, D., van der Werf, S., Guery, B., and M. E.-C. B. Group. 2014. Kinetics and pattern of viral excretion in biological specimens of two MERS-CoV cases. J. Clin. Virol. 61, 275278.

Reusken, C.B., Haagmans, B.L., Muller, M.A., Gutierrez, C., Godeke, G.J., Meyer, B., Muth, D., Raj, V.S., Smits-De Vries, L., Corman, V.M., et al. 2013a. Middle East respiratory syndrome coronavirus neutralising serum antibodies in dromedary camels: a comparative serological study. Lancet Infect. Dis. 13, 859-866.

Reusken, C., Mou, H., Godeke, G.J., van der Hoek, L., Meyer, B., Muller, M.A., Haagmans, B., de Sousa, R., Schuurman, N., Dittmer, U., et al. 2013b Specific serology for emerging human coronaviruses by protein microarray. Euro Surveill. 18, pii=20441.

Scheuplein, V.A., Seifried, J., Malczyk, A.H., Miller, L., Hocker, L., Vergara-Alert, J., Dolnik, O., Zielecki, F., Becker, B., Spreitzer, I., et al. 2015. High secretion of interferons by human plasmacytoid dendritic cells upon recognition of Middle East respiratory syndrome coronavirus. J. Virol. 89, 3859-3869.

Seong, M.W., Lee, S.J., Cho, S.I., Ko, K., Kim, M.N., Sung, H., Kim, J.S., Ahn, J.S., Yu, B.S., Kim, T.S., et al. 2016. External quality assessment of MERS-CoV molecular diagnostics during the 2015 Korean Outbreak. Ann. Lab. Med. 36, 230-234.

Shirato, K., Yano, T., Senba, S., Akachi, S., Kobayashi, T., Nishinaka, T., Notomi, T., and Matsuyama, S. 2014. Detection of Middle East respiratory syndrome coronavirus using reverse transcription loop-mediated isothermal amplification (RT-LAMP). Virol. J. $11,139$.

Song, D., Ha, G., Serhan, W., Eltahir, Y., Yusof, M., Hashem, F., Elsayed, E., Marzoug, B., Abdelazim, A., and Al Muhairi, S. 2015. Development and validation of a rapid immunochromatographic assay for detection of Middle East respiratory syndrome coronavirus antigen in dromedary camels. J. Clin. Microbiol. 53, 11781182

Sridhar, S., To, K.K., Chan, J.F., Lau, S.K., Woo, P.C., and Yuen, K.Y. 2015. A systematic approach to novel virus discovery in emerging infectious disease outbreaks. J. Mol. Diagn. 17, 230-241.

Sung, H., Yong, D., Ki, C.S., Kim, J.S., Seong, M.W., Lee, H., and Kim, M.N. 2016. Comparative evaluation of three homogenization methods for isolating Middle East respiratory syndrome coronavirus nucleic acids from sputum samples for real-time reverse transcription PCR. Ann. Lab. Med. 36, 457-462.

Tang, X.C., Agnihothram, S.S., Jiao, Y., Stanhope, J., Graham, R.L., Peterson, E.C., Avnir, Y., Tallarico, A.S., Sheehan, J., Zhu, Q., et al. 2014. Identification of human neutralizing antibodies against MERS-CoV and their role in virus adaptive evolution. Proc. Natl. Acad. Sci. USA 111, E2018-2026.

To, K.K., Chan, J.F., Chen, H., Li, L., and Yuen, K.Y. 2013. The emergence of influenza A H7N9 in human beings 16 years after influenza A H5N1: a tale of two cities. Lancet Infect. Dis. 13, 809-821.

To, K.K., Chan, J.F., Tsang, A.K., Cheng, V.C., and Yuen, K.Y. 2015. Ebola virus disease: a highly fatal infectious disease reemerging in West Africa. Microbes Infect. 17, 84-97.

To, K.K., Tsang, A.K., Chan, J.F., Cheng, V.C., Chen, H., and Yuen, K.Y. 2014. Emergence in China of human disease due to avian influenza A(H10N8)-cause for concern? J. Infect. 68, 205-215.

Tynell, J., Westenius, V., Ronkko, E., Munster, V.J., Melen, K., Osterlund, P., and Julkunen, I. 2016. Middle East respiratory syndrome coronavirus shows poor replication but significant induction of antiviral responses in human monocyte-derived macrophages and dendritic cells. J. Gen. Virol. 97, 344-355.

Uyeki, T.M., Erlandson, K.J., Korch, G., O'Hara, M., Wathen, M., 
Hu-Primmer, J., Hojvat, S., Stemmy, E.J., and Donabedian, A. 2016. Development of medical countermeasures to Middle East respiratory syndrome coronavirus. Emerg. Infect. Dis. 22, DOI: 10.3201/eid2207.160022.

Wang, Q., Qi, J., Yuan, Y., Xuan, Y., Han, P., Wan, Y., Ji, W., Li, Y., Wu, Y., Wang, J., et al. 2014. Bat origins of MERS-CoV supported by bat coronavirus HKU4 usage of human receptor CD26. Cell Host Microbe 16, 328-337.

Wang, W., Wang, H., Deng, Y., Song, T., Lan, J., Wu, G., Ke, C., and Tan, W. 2016a. Characterization of anti-MERS-CoV antibodies against various recombinant structural antigens of MERS-CoV in an imported case in China. Emerg. Microbes Infect. 5, e113.

Wang, W.L., Wang, H.J., Deng, Y., Song, T., Lan, J.M., Wu, G.Z., Ke, C.W., and Tan, W.J. 2016b. Serological study of an imported case of Middle East respiratory syndrome and his close contacts in China, 2015. Biomed. Environ. Sci. 29, 219-223.

Wernery, U., El Rasoul, I.H., Wong, E.Y., Joseph, M., Chen, Y., Jose, S., Tsang, A.K., Patteril, N.A., Chen, H., Elizabeth, S.K., et al. 2015. A phylogenetically distinct Middle East respiratory syndrome coronavirus detected in a dromedary calf from a closed dairy herd in Dubai with rising seroprevalence with age. Emerg. Microbes Infect. 4, e74.

Woo, P.C., Lau, S.K., Li, K.S., Tsang, A.K., and Yuen, K.Y. 2012. Genetic relatedness of the novel human group $\mathrm{C}$ betacoronavirus to Tylonycteris bat coronavirus HKU4 and Pipistrellus bat coronavirus HKU5. Emerg. Microbes Infect. 1, e35.

Woo, P.C., Lau, S.K., Wong, B.H., Chan, K.H., Chu, C.M., Tsoi, H.W., Huang, Y., Peiris, J.S., and Yuen, K.Y. 2004. Longitudinal profile of immunoglobulin $\mathrm{G}(\mathrm{IgG})$, IgM, and $\operatorname{IgA}$ antibodies against the severe acute respiratory syndrome (SARS) coronavirus nucleocapsid protein in patients with pneumonia due to the SARS coronavirus. Clin. Diagn. Lab. Immunol. 11, 665-668.

Woo, P.C., Lau, S.K., Wong, B.H., Tsoi, H.W., Fung, A.M., Kao, R.Y., Chan, K.H., Peiris, J.S., and Yuen, K.Y. 2005. Differential sensitivities of severe acute respiratory syndrome (SARS) coronavirus spike polypeptide enzyme-linked immunosorbent assay (ELISA) and SARS coronavirus nucleocapsid protein ELISA for serodiagnosis of SARS coronavirus pneumonia. J. Clin. Microbiol. 43, 3054-3058.

Yamaoka, Y., Matsuyama, S., Fukushi, S., Matsunaga, S., Matsushima, Y., Kuroyama, H., Kimura, H., Takeda, M., Chimuro, T., and Ryo, A. 2016. Development of monoclonal antibody and diagnostic test for Middle East respiratory syndrome coronavirus using cell-free synthesized nucleocapsid antigen. Front. Microbiol. 7, 509 .

Yao, Y., Bao, L., Deng, W., Xu, L., Li, F., Lv, Q., Yu, P., Chen, T., Xu, Y., Zhu, H., et al. 2014. An animal model of MERS produced by infection of rhesus macaques with MERS coronavirus. J. Infect. Dis. 209, 236-242.

Yaren, O., Glushakova, L.G., Bradley, K.M., Hoshika, S., and Benner, S.A. 2016. Standard and AEGIS nicking molecular beacons detect amplicons from the Middle East respiratory syndrome coronavirus. J. Virol. Methods 236, 54-61.

Yeung, M.L., Yao, Y., Jia, L., Chan, J.F., Chan, K.H., Cheung, K.F., Chen, H., Poon, V.K., Tsang, A.K., To, K.K., et al. 2016. MERS coronavirus induces apoptosis in kidney and lung by upregulating Smad7 and FGF2. Nat. Microbiol. 1, 16004.

Ying, T., Du, L., Ju, T.W., Prabakaran, P., Lau, C.C., Lu, L., Liu, Q., Wang, L., Feng, Y., Wang, Y., et al. 2014. Exceptionally potent neutralization of Middle East respiratory syndrome coronavirus by human monoclonal antibodies. J. Virol. 88, 7796-7805.

Zaki, A.M., van Boheemen, S., Bestebroer, T.M., Osterhaus, A.D., and Fouchier, R.A. 2012. Isolation of a novel coronavirus from a man with pneumonia in Saudi Arabia. N. Engl. J. Med. 367, 1814-1820.

Zhang, L., Hao, M., Zhang, K., Zhang, R., Lin, G., Jia, T., Zhang, D., Chang, L., Xie, J., and Li, J. 2016. External quality assessment for the molecular detection of MERS-CoV in China. J. Clin. Virol. 75, $5-9$.

Zhao, J., Li, K., Wohlford-Lenane, C., Agnihothram, S.S., Fett, C., Zhao, J., Gale, M.J., Baric, R.S.Jr., Enjuanes, L., Gallagher, T., et al. 2014. Rapid generation of a mouse model for Middle East respiratory syndrome. Proc. Natl. Acad. Sci. USA 111, 4970-4975.

Zhou, J., Chu, H., Chan, J.F., and Yuen, K.Y. 2015. Middle East respiratory syndrome coronavirus infection: virus-host cell interactions and implications on pathogenesis. Virol. J. 12, 218.

Zhou, J., Chu, H., Li, C., Wong, B.H., Cheng, Z.S., Poon, V.K., Sun, T., Lau, C.C., Wong, K.K., Chan, J.Y., et al. 2014. Active replication of Middle East respiratory syndrome coronavirus and aberrant induction of inflammatory cytokines and chemokines in human macrophages: implications for pathogenesis. J. Infect. Dis. 209, 1331-1342.

Zumla, A., Chan, J.F., Azhar, E.I., Hui, D.S., and Yuen, K.Y. 2016. Coronaviruses - drug discovery and therapeutic options. Nat. Rev. Drug. Discov. 15, 327-347. 